\title{
EVOLUȚIA LEGISLATIVĂ ȘI ISTORIA STUDIILOR DOCTORALE DIN ROMÂNIA ÎNTRE 1898 ȘI 1995
}

Rezumat: Tematica pe care se pliază prezentul material este reprezentată de analiza legislației educaționale, văzută în context istoric. Prin urmare, în prezentul material intenționez fundamentarea unui studiu de referință privitor la studiile doctorale înainte, în timpul, şi imediat după perioada comunistă în România. Acest material aduce un mare aport doctrinei de dreptul educației instituționale, întrucât un asemenea studiu, care să analizeze evoluția legislativă a studiilor doctorale românești nu a fost făcut încă. În ordine cronologică, acest studiu va expune şi analiza elementele inovative sau de revenire la vechi tradiții doctorale care au apărut pe parcursul istoriei. Cele două mari perioade istorice reprezentative sunt date de studiile doctorale din timpul Regatului României, între anii 1898 și 1948, și cele date de perioada regimului comunist, cuprinse între 1948 şi 1989. Studiul dorește prezentarea firului evolutiv constant dat de elementul susținerii publice a tezei de doctorat în jurul căruia s-au circumscris de-a lungul timpului diferite intervenții regale, comuniste sau pur universitare pentru a defini fiecare deceniu de studii doctorale în România.

Cuvinte-cheie: Istoria doctoratului, Legea educației, învățământ superior, studii doctorale.

* Master în Științe penale și Criminalistică, Facultatea de Drept a Universității Babeș-Bolyai. 


\title{
THE LEGISLATIVE EVOLUTION AND HISTORY OF DOCTORAL STUDIES IN ROMANIA BETWEEN 1898 AND 1995
}

\begin{abstract}
The theme within the present material unfolds is represented by the analysis of the educational legislation, seen in historical context. Therefore, in this material I intend to base a reference study on doctoral studies before, during, and immediately after the communist period in Romania. This material brings a great contribution to the doctrine of the law of institutional education, as such a study, which analyzes the legislative evolution of the Romanian doctoral studies has not yet been done. In chronological order, this study will expose and analyze the innovative or returning elements of old doctoral traditions that have appeared throughout history. The two great representative historical periods are given by the doctoral studies during the Kingdom of Romania, between 1898 and 1948, and those given by the period of the communist regime, between 1948 and 1989. The study wants to present the constant evolutionary thread given by the element of the public defence of the doctorate thesis around which different royal, communist or purely academic interventions have been circumscribed over time to define each decade of doctoral studies in Romania.
\end{abstract} Studies.

Keywords: Doctorate History, Education Law, Higher Education, Doctoral

\section{Introducere.}

\subsection{Aspecte preliminarii.}

Lucrarea de față este structurată în 3 mari capitole. Capitolul introductiv, tratează inițial aspectele preliminarii ale prezentului studiu, aducând în prim - plan organizarea materialului. Introducerea continuă apoi cu metodologia lucrării, care prezintă scopul studiului între limitările sale inerente, urmând ca partea introductivă să se încheie cu reperele legislative avute în vedere în configurarea acestui articol, unde se prezintă în 
ordine cronologică legislația învățământului ce a adus efectele principale în sfera studiilor doctorale în România.

Al doilea capitol al lucrării devine astfel prezentarea şi analiza perioadelor istorice care prefigurează evoluția legislativă a studiilor doctorale ce fac obiectul studiului acesta. Așadar, în primul subcapitol este tratată perioada anilor 1864 - 1948, perioadă în care studiile doctorale în România prind formă și în care se dezvoltă anumite tradiții specifice perioadei istorice ante-comuniste. Al doilea subcapitol tratează studiile doctorale în România comunistă, perioadă istorică în care evoluția legislativă a studiilor doctorale suferă o „ștergere cu buretele” a întregii experiențe anterioare şi o impunătoare amprentă estică. Ultimul subcapitol analizează perioada pregnant tranzitivă a anilor 1990-1996, în care studiile doctorale în România așteaptă desprinderea de elementele comunismului și apariția unei legi a învăţământului noi. Fiecare subcapitol figurează propriile concluzii.

Ultimul capitol al lucrării sunt concluziile care prefigurează elementele constante și fluctuante prezentate în acest material și reflecțiile asupra perioadei de după 1996.

\subsection{Metodologie.}

Conceptul în jurul căreia se circumscrie prezentul material, face apel în principal la legislația primară și secundară ce a reglementat studiile doctorale în România. Pe de altă parte, voi face abstracție de practica doctoratului, date fiind limitările impuse de însuşi scopul lucrării, și anume evidenţierea legislației primare ce reglementa studiile doctorale. Prin urmare, voi scoate în evidență „curentul evolutiv principal”, transformările general valabile care s-au abătut asupra traseului legislativ doctoral românesc, făcând desigur trimiteri şi la legislația secundară sau terțiară acolo unde este necesar.

\section{3}


De altfel, voi pune accentul pe cadrul temporal de dinainte de perioada comunistă. Aceasta se datorează în primul rând faptului că acea perioadă reprezintă începutul voit al tradiției doctorale românești. De altfel, perioada doctoratului în Regatul României poate fi cercetată mai uşor, din cauza faptului că doar din 1 Ianuarie 1928 Monitorul Oficial s-a împărțit în 3 părții ${ }^{1}$, și datorită caracterului represiv al perioadei comuniste, care nu permite de altfel descoperirea actelor normative secundare și terţiare care reglementau studiile doctorale românești din acea perioadă. De menționat ar fi că nu voi face referire la doctoratul în medicină, dat fiind specificul lui de a atribui titlul de doctor persoanelor care urmează să practice medicina.

Prin urmare, cele trei mari perioade care caracterizează evoluția doctoratului românesc sunt cele cuprinse între: A. 1898 - apariția primei legi care reglementa organizarea doctoratului în România - și 1948; B. 1948 instaurarea pauzei doctorale tradiționale și apariția reformei învățământului - şi 1989; și C. 1989 - prezent. În final, studiul meu se oprește cu anul 1996, întrucât imensitatea reglementărilor venite după anul 1995 și până în 2019 pot face obiectul doar a unor studii ulterioare.

\subsection{Repere legislative.}

Având în vedere faptul că studiul de față este unul cu referire la legislația regăsită în Monitorul Oficial, trebuie să stabilim actele normative călăuzitoare, împărțite pe trei perioade temporale, care să ne ghideze și limiteze în demersul nostru.

Astfel, pentru perioada de început, în care se pun bazele evoluției doctoratului românesc, perioada care va fi expusă mai detaliat, cu exemple

\footnotetext{
${ }^{1}$ Direcţiunea Monitorului Oficial și Imprimeriei Statului, Monitorul Oficial. 100 de ani. 18321932, Imprimeria Națională, Bucureșt, 1932, pp. 19-22.
} 
de regulamente universitare, sau alte mențiuni, regăsite în M.of. Cercetarea legislației privind studiile doctorale din România dintre 1864 şi 1948 are în vedere în principal:

1. „Legea nr. 1150 din 25 noiembrie 1864 asupra instrucțiunii a Principateloru-Unite-Române"2;

2. „Legea asupra învěțămêntulŭ secundar și superior”;;

3. „Legea pentru modificarea unor articole din legea administrațiunei centrale a ministerului cultelor și instrucțiunei publice de la 31 August 1892, din legea clerului mirean și seminariilor, din legea învěţămîntului primar și normal de la 29 Aprilie 1896, din legea învěţămîntului secundar și superior din 23 Martie 1898 şi legea învěțămîntului profesional din 31 martie 1899, precum și pentru adăogarea unor noul̆ articole"4;

4. „Legea pentru modificarea unor articole din legea asupra învățământului secundar și superior”, 5 ;

5. Legea pentru organizarea învățământului universitar”6;

6. „Decretul-lege relativ la organizarea învățământului superior”;

Pentru perioada 1948 - 1989, vom avea în vedere drept repere următoarele acte normative:

2 Publicată în M.of. din 25 noiembrie 1864. Accesibilă și pe http://legislatie.just.ro/Public/DetaliiDocument/21331.

3 Publicată în M.of.: 283 din 24 martie/6 aprilie 1898.

4 Publicată în M.of.: 6 din 7 aprilie/20 aprilie 1900.

5 Publicată în M.of.: 283 din 24 martie/ 6 aprilie 1912. A se observa coincidența datelor legilor din 1898, respectiv 1912.

6 Publicată în M.of.: 96 din 22 aprilie 1932.

7 Publicat în M.of.: 118 din 23 mai 1942. 
7. „Decretul nr. 175 pentru reforma învățământului”;

8. „Decretul nr. 13 din 14 Ianuarie 1950 pentru înființarea și organizarea aspiranturii"9;

9. „Decret nr. 14 din 14 Ianuarie 1950 pentru reglementarea aspiranturii în condiții speciale"10;

10. „Decretul nr. 15 din 14 Ianuarie 1950 pentru organizarea doctoratului"11;

11. „Legea nr. 4 din 30 mai 1950 pentru ratificarea decretelor emise de Prezidiul Marii Adunări Naţionale în perioada dela 23 Decemvrie 1949 până la 27 Mai 1950"12;

12. „Decretul nr. 1058 din 15 Noiembrie 1967 privind titlurile științifice în Republica Socialistă România"13;

13. „Hotărârea nr. 2910 din 29 Noiembrie 1967 pentru aplicarea Decretului nr. 1058/1967 privind titlurile științifice în Republica Socialistă România"14;

\footnotetext{
8 Publicat în M.of.: 177 din 3 August 1948. Accesibil și pe https://lege5.ro/Gratuit/g42domzq/decretul-nr-175-1948-pentru-reformainvatamantului?pid=68644252\#p-68644252.

9 Publicat în B.of.: 4 din 17 Ianuarie 1950. Accesibil și prin intermediul portalului https://idrept.ro/.

10 Publicat în B.of.: 4 din 17 Ianuarie 1950. Accesibil și prin intermediul portalului https://idrept.ro/.

${ }^{11}$ Publicat în B.of.: 4 din 17 Ianuarie 1950. Accesibil și pe http://www.monitoruljuridic.ro/act/decret-nr-15-din-14-ianuarie-1950-pentru-organizareadoctoratului-emitent-marea-adunare-nationala-publicat-n-buletinul-22070.html.

12 Publicată în B.of.: 50 din 8 Iunie 1950. Accesibilă și pe www.cdep.ro/pls/legis/legis_pck.htp_act_text?idt=27811.

13 Publicat în B.of.: 100 din 15 Noiembrie 1967. Accesibil și pe http://www.monitoruljuridic.ro/act/decret-nr-1058-din-15-noiembrie-1967-privind-titlurilestiintifice-in-republica-socialista-romania-emitent-consiliul-de-stat-publicat-n-187.html. 14 Publicată în B.of.: 101 din 1 Decembrie 1967. Accesibilă și pe http://www.monitoruljuridic.ro/act/hotarare-nr-2-910-din-29-noiembrie-1967-pentru-aplicarea-
}

\section{6}


14. Legea nr. 11 din 13 mai 1968 privind învățămîntul în Republica Socialistă România"15;

15. „Legea nr. 28 din 21 Decembrie 1978 legea educației şi învățămîntului”'16;

Pentru perioada anilor 1989 - 1995, reperele legislative tranzitive și finale sunt:

16. „Hotărârea nr. 521 din 12 Mai 1990 privind organizarea şi funcționarea învățămîntului în România în anul școlar (universitar) 1990/1991"17;

17. „Hotărârea nr. 461 din 30 Iunie 1991 privind organizarea şi funcționarea învățământului în România în anul școlar (universitar) 1991/1992"18;

18. „Hotarârea nr. 283 din 21 Iunie 1993 privind unele măsuri referitoare la desfăşurarea învăţământului în anul şcolar (universitar) 1993/1994"19;

drecretului-nr-1050-1967-privind-titlurile-stiintifice-in-republica-socialista-romania-emitent-

consiliul-de-ministri-22721.html.

15 Publicată în B.of.: 62 din 13 Mai 1968. Accesibil şi pe http://www.monitoruljuridic.ro/act/legenr-11-din-13-mai-1968-privind-invatamintul-in-republica-socialista-romania-emitent-marea-adunarenationala-publicat-n-46715.html.

16 Publicată în B.of.: 113 din 26 Decembrie 1978. Accesibil și pe

http://www.monitoruljuridic.ro/act/legea-educatiei-si-invatamintului-nr-28-din-21-decembrie-1978legea-educatiei-si-invatamintului-emitent-marea-adunare-nationala-publicat-n-466.html.

17 Publicată în M.of.: 71 din 16 Mai 1990. Accesibilă și prin intermediul portalului https://idrept.ro/.

18 Publicată în M.of.: 157 din 25 Iulie 1991. Accesibilă şi pe

http://www.monitoruljuridic.ro/act/hotarare-nr-461-din-30-iunie-1991-privind-organizarea-sifunctionarea-invatamantului-in-romania-in-anul-scolar-universitar-1991-1992-emitent-guvernul92359.html.

19 Publicată în M.of.: 171 din 22 Iulie 1993. Accesibilă și pe http://www.monitoruljuridic.ro/act/hotarire-nr-283-din-21-iunie-1993-privind-unele-masuri-

\section{7}


19. „Legea nr. 84 din 24 Iulie 1995 Legea învățământului”20;

20. „Hotărârea nr. 301 din 30 Aprilie 1996 privind organizarea şi desfăşurarea doctoratului”" ${ }^{21}$.

2 Două perioade legislative doctorale, două tranziții, și începutul celei de-a treia.

\subsection{Anii $1864-1948$.}

2.1.1 Perioada incipientă a studiilor doctorale românești.

$1^{22}$. Deși în 1864 apare „Legea nr. 1150 din 25 noiembrie 1864 asupra instrucțiunii a Principateloru-Unite-Române”, lege de inspiraţie universitară franceză ${ }^{23}$, această lege avea în vedere în prim plan, în ceea ce privește „Instrucțiunea superioare”, organizarea facultăților, facultăţi care, mai multe „aflânduse înființate într'o localitate constituiescu o universitate”. Accentul deci în această lege, din perspectiva învățământului superior este doar punerea bazelor învățământului superior, fără a se porni o aventurare în

referitoare-la-desfasurarea-invatamantului-in-anul-scolar-universitar-1993-1994-emitent-guvernaparut-in-3446.html.

20 Publicată în M.of.: 167 din 31 Iulie 1995. Accesibilă și pe

http://www.monitoruljuridic.ro/act/lege-nr-84-din-24-iulie-1995-legea-invatamintului-emitentparlamentul-romaniei-publicat-n-monitorul-oficial-nr-6170.html, accesat în 20.05.2019.

${ }^{21}$ Publicată în M.of.: 102 din 20 Mai 1996. Accesibilă și pe http://www.monitoruljuridic.ro/act/hotarire-nr-301-din-30-aprilie-1996-privind-organizarea-sidesfasurarea-doctoratului-emitent-guvernul-publicat-n-monitorul-9046.html.

${ }^{22}$ Numerele înscrise înainte alineatelor care desemnează începerea discuției pe marginea legii/decretului/hotărârii aferente corespund numerelor arondate legislației expusă în subcapitolul „Repere legislative.”.

23 Cătălin Botoşineanu, „Recrutarea corpului profesoral al universităţii din Iași la începutul epocii interbelice. Cazul Petre Andrei”, Anuarul Institutului de Istorie „George Barițiu” Series Historica, nr. 47, 2008, p. 219, nota de subsol 1. 
înființarea studiilor doctorale românești. Partea I a L. 1864 face referire prin titlul său „doar” la „Despre administrațiunea şi organisarea instrucțiunii”, iar Capitolul 4 al Părții I, denumit „Instrucțiunea superioare” nu vorbește în cele III Secțiuni ale sale (art. 249-310) de instituirea unor studii doctorale, principalul obiectiv al acestui Capitol 4 fiind deci punerea bazelor instituționale universitare.

De altfel, în „discuțiunei Sedinței Adunărieŭ deputaților de la 19 Ianuarie” 1877²4, s-a discutat 25 intens acel: „desideratum, dorim să ajungem acolo când vom avea uă facultate de drept complectă, adică care să dea și doctoř în drept, éră nu numai licențiaț̌̆”, deziderat care avea să se întâmple în anul 1898.

2. Astfel, în 1898 odată cu „Legea asupra învěțămêntuluŭ secundar și superior”, inițiată de ministrul liberal Spiru Haret (cunoscută drept „legea Haret”) s-a impus tipul german de organizare ${ }^{26}$, tip de organizare care avea să pună și bazele studiilor doctorale românești.

O lege înnoitoare ${ }^{27}$, promovând ideea haretistă a autonomiei universitare ${ }^{28}$, cu un rol deosebit de important în dezvoltarea învăţământului superior românesc ${ }^{29}$, făcând parte dintr-un grup de măsuri prin care se dorea

24 Publicată în Partea Neoficială a Monitorului Oficial nr. 22 din 29 Ianuarie/10 februarie 1877.

25 Paginile 696 - 698 din M.of. la care ne referim.

${ }^{26}$ Cătălin Botoșineanu, op. cit., p. 219.

${ }_{27}$ Anghel Manolache, Gheorghe Pârnuță, Istoria învățământului din România. Vol. II (18211918), Editura Didactică și Pedagogică, București, 1993, p. 345.

28 Iolanda Constantinescu, „Contribuția academicianului Spiru Haret la dezvoltarea învățământului românesc”, CRIFST - Studii și Comunicări, vol. 5, 2012, p. 316.

29 Lilia Parhomenco, „Dezvoltarea învățământului în spațiul carpato-danubiano-pontic”, Revista Științifică a Universității de Stat din Moldova - Seria „Științe ale educației”, vol. 69, nr. 9, 2013, p. 43 . 
introducerea unui regim mai rațional în învățământ ${ }^{30}$, cu 114 articole, puse în 5 capitole, „bine legate între ele”31, L. 1898 prevedea înființarea treptată a studiilor şi acordarea diplomelor de doctorat (doctoratul în medicină nu face obiectul prezentului studiu), cu mijloacele financiare și cu oamenii de ştiință de care se dispunea în acea perioadă ${ }^{32}$. S-a apreciat că la sfârşit de veac, prin L. 1898, învățământul românesc „s-a așezat”33, dar în această așezare studiul doctoral abia începuse să încerce să se facă confortabil.

Așadar, prin art. 60 al L. 1898, care reprezintă articolul principal vizavi de obținerea diploma de doctorat 34 , se prevedea că „Fie-care Universitate va libera duoĕfelurŭ de diplome: diploma de licență, și diploma de doctorat". Totuși, condițiile de fond și de formă care trebuiau îndeplinite pentru a obține diploma de doctor urma să se facă printr-un „regulament comun, elaborat de comisiunı̆ mixte din ambele Universităț̆̌̆ 35 , împreună cu delegaț̆ ă ministrulŭ̆, va stabili cař sunt, pentru fie-care facultate și secțiune", lucru pe care îl aflăm în art. 60 al L. 1898. În orice caz, cu rang de lege primară și titlu de regulă imperativă, același art. 60 al L. 1898 stabilea că înaintea obținerii diplomei de doctorat „în nič̆ un cas, numĕrul anilor de studiŭ în o specialitate nu va putea fi mă mic de [...] 5 pentru doctorat" ${ }^{36}$.

Exemplificând, în M.of.: 151 din 6/18 Octombre 1899, Partea Oficială regăsim „Decretul relativ la regulamentul pentru Facultatea de Teologie din

\footnotetext{
$3^{0}$ Jean Banciu, Istoria învățământului din România de la primele începuturi până în anul 199o, Editura Pro Universitaria, București, 2010, p. 77.

${ }^{1}$ Anghel Manolache, Gheorghe Pârnuță, op. cit., p. 344.

$3^{2}$ Iolanda Constantinescu, op. cit., p. 317.

33 Anghel Manolache, Gheorghe Pârnuță, op. cit., p. 343.

$34 \mathrm{Nu}$ luăm în calcul abilitarea, care deja presupunea deținerea titlului de doctor. Vezi art. 64 şi urm. ale L. 1898.

35 Art. 53 din L. 1898: „Universităţile sunt duoě: una în Bucureșč̆ şi alta în laş̌̌”.

${ }^{36}$ Art. 60 din L. 1898.
} 
Bucuresci”, care ne dă o idee despre modul în care, teoretic, se putea obține titlul de doctor în teologie. În linii mari, după cei patru ani de licență37, studenții urmau un al doilea examen de $\operatorname{stat}^{38}$, iar promovarea acestuia le dădea titlul de „candidat de licențiat”39, titlu cu care studentul la teologie putea să își susțină teza de licență în fața comisiei examinatoare, iar în cazul admiterii examinării publice primea titlul de „licențiat în teologie” 40 . Totuşi, dacă studentul aspira la titlul de doctor, trebuia să urmeze şi cursurile anului al V-lea, la sfârșitul căruia urma o examinare publică generală a studiilor acelui an, a cărei promovare îl făcea pe student doctorand în teologie ${ }^{41}$. De notat ar fi că, deși studenții proveniți din alte facultăți putea urma cursurile anului al V-lea în teologie, aceștia nu puteau fi primiți în examenul care le conferea titlul de doctoranzi în teologie, fără ca înainte să devină licențiaţi și în teologie ${ }^{42}$. În final, titlul de doctor se obținea după cel puțin 5 ani de dezvoltare a unui „tratat șcïnțific” teologic, diferit de teza de licență, care urma să se susțină, oricând în timpul anului universitar, în paralel cu examinarea publică a unei comisii, care conferea titlul de admis, proclamând astfel doctorandul în doctor în teologie43.

3. La scurt timp după L. 1898, în 1900 apare „Legea pentru modificarea unor articole din legea administrațiunei centrale a ministerului cultelor și instrucțiunei publice de la 31 August 1892, din legea clerului mirean și seminariilor, din legea învěțămîntului primar şi normal de la 29 Aprilie 1896, din legea învěţămîntului secundar și superior din 23 Martie

\footnotetext{
37 Art. 2 din R. pentru Facultatea de Teologie din Bucuresci, 1899.

${ }^{38}$ Art. 43 din R. pentru Facultatea de Teologie din Bucuresci, 1899.

39 Art. 46 R. pentru Facultatea de Teologie din Bucuresci, 1899.

${ }^{40}$ Art. 52 R. pentru Facultatea de Teologie din Bucuresci, 1899.

${ }^{41}$ Art. 53, 54 şi 56 din R. pentru Facultatea de Teologie din Bucuresci, 1899.

${ }^{42}$ Art. 57 din R. pentru Facultatea de Teologie din Bucuresci, 1899.

43 Art. 58 - 64 din R. pentru Facultatea de Teologie din Bucuresci, 1899.
} 
1898 și legea învěţămîntului profesional din 31 Martie 1899, precum și pentru adăogarea unor nouı̆ articole", care prin art. XI44 modifică, printre altele, și art. 60 din L. 1898, căruia i se adaugă un nou alin. ce făcea referire la intervenția regală în materie doctorală.

Prin urmare, pe lângă imixtiunea „Ministerului cultelor şi instrucțiuneĭ publice”, reprezentat în 1900 de ministrul C. I. Istrati, în elaborarea regulamentelor facultăților, imixtiune care desigur urma să aibă influențe şi asupra studiilor doctorale, acum se adaugă şi influența regală în obținerea studiilor doctorale. Înainte de L. 1900 Universitatea putea elibera diploma de doctor fără implicarea altor instituții sau membri ai conducerii statului, în orice domeniu. Odată cu L. 1900 se specifică, conform noului alin. al art. 60 din Legea învățământului superior, că în domeniile „drept, litere, şciințe și teologie” nu se „vor putea libera diploma de doctor de cât dupe ce un decret regal va fi hotărît acésta" 45 . Se poate observa că doctorandul primea titlul de doctor în „drept, litere, șciințe sau teologie”, prin decret regal, iar nu prin simpla acordare a acestui titlu din partea Universității.

Această adăugare „regală” se regăsește astfel în „Decretul relativ la funcţiunea și aprobarea regulamentului facultăţii de litere şi filozofie din București” din 190846. Conform acestui regulament, pentru a deveni doctor în filozofie și litere trebuiau urmați mai mulți pași, iar conform art. 12 diploma de doctor se „da in numele M. S. Regelui, va purtà sigiliul cel mare al universității și va fi semnată de ministrul instrucțiunii publice, de rectorul universității și de decanul facultății. Ea va fi tipărită pe pergament”.

\footnotetext{
44 Articolele L. 1900 erau numerotate cu numere romane pentru a evita confuziile ce puteau apărea cu privire la articolele din L. 1898, numerotate cu numere arabe, ce urmau a fi modificate.

45 Art. 60 din L. 1900.

${ }^{46}$ Publicat în M.of.: 115 din 22 August/4 Septemvrie 1908, Partea Oficială.
} 
Coroborând art. 3, 12 - 14 și 44 - 49 din acest regulament, pentru obținerea titlului de doctor, un aspirant trebuie să dețină titlul de „licențiat în filozofie și litere”, să participe „cel puțin un an, după trecerea examenului de licență, la lucrările de seminar ale specialității în care voește să'și treacă doctoratul"47, „să prezinte o dizertație originală asupra unui subiect ales de dânșii din materiile facultății" 48 și să își susțină teza de doctorat în concomitent cu un examen doctoral oral, ultimele două compunând examenul de doctorat, în urma căruia candidatul era admis sau respins.

În orice caz, acordarea titlului de doctor și examenul pentru diploma de doctor aveau drept „scop să dovedească întrucât candidatul a isbutit să aprofundeze o specialitate, aşa ca să poată lucra cu succes la dezvoltrea mai de parte a științei în care s'a specializat"49 candidatul.

În M.of: 44 din 27 Maiu/9 Iunie 1909, Partea Oficială, prin decret se aprobă „Regulamentul Facultății de Drept din Iași”. Conform acestui regulament, studiile doctorale, înaintate de cele de licență cu o durată de 3 ani, se reduc la o durată „de doui ani cel puțin” $5^{\circ}$. La doctorat se puteau înscrie licențiații unei facultăți, care, devenind candidați, urmau să susțină examenele de doctorat ce erau „de două feluri: examenele de fine de an și examenul final; acesta din urmă se va compune din susținerea unei teze și din susținerea pozițiunilor alese" ${ }^{51}$. Examenele de fine de an erau date în fața a patru profesori examinatori, în timp ce susținerea urmând a „trece înaintea unei comisii de cinci profesori” ${ }^{2}$, însă toate trebuiau a fi susținute în una din

\footnotetext{
47 Art. 44 din R. Facultății de Litere și Filozofie din București, 1908.

48 Art. 14 din R. Facultății de Litere și Filozofie din București, 1908.

49 Art. 12 din R. Facultăţii de Litere şi Filozofie din București, 1908.

50 Art. 7 din R. Facultăţii de Drept din Iași, 1909.

${ }^{11}$ Art. 31 din R. Facultății de Drept din Iași, 1909.

$5^{2}$ Art. 31 din R. Facultăţii de Drept din Iași, 1909.
} 
lunile „Octomvrie, Ianuarie şi Iunie”53. În urma susținerii cu succes a tezei de doctorat, rezultatul se dădea ,îndată după terminare” 54 , „președintele proclama doctor pe candidat"55, urmând ca diploma sa de doctor să fie emisă în baza decretului regal.

4. În 1912, învățământul superior se modifică pentru a 3 - a oară, prin „Legea pentru modificarea unor articole din legea asupra învățământului secundar şi superior", care modifică, de fapt, doar învățământul superior.

Considerată o lege ce sporea autonomia universitarăs ${ }^{5}$, drepturile organelor de conducere a universității, organizarea facultăților şi a vieții studențești, modul de obținere a diplomelor universitare57, L. 1912, cunoscută drept „Legea Arion”, după numele Ministrului Instrucțiunii din guvernul conservator Titu Maiorescu ${ }^{8}$, transformă art. 53 - 114, prin adăugarea de alin. noi sau făcându-se modificări de alin. în art. 53 - 127.

L. 1912 introduce norme care restrâng aria de competență a Universităților și Ministerului. Aceasta se concretiza prin regulamentele universitare, nelăsând astfel stabilirea regulilor pe seama acelor Comisii mixte. Astfel, poate din punct de vedere istoric, L. 1912 aducea mai multă autonomie universitară, dar din punct de vedere normativ, prin legiferarea primară a regulilor universitare, implicit în domeniul doctoral, se restrângea prerogativa universităților de a-şi stabili singure regulile.

Conținutul fostului art. 60 din L. din 1898 și 1900 este preluat prin L. 1912 în art. 64, iar după art. 64, prin L. 1912, art. 65-67 ajung să

\footnotetext{
53 Art. 32 din R. Facultății de Drept din Iași, 1909.

54 Art. 32 din R. Facultății de Drept din Iaşi, 1909.

55 Art. 35 din R. Facultății de Drept din Iaşi, 1909.

${ }^{56}$ Lilia Parhomenco, op. cit., p. 43.

57 Anghel Manolache, Gheorghe Pârnuță, op. cit., p. 345.

$5^{8}$ Cătălin Botoșineanu, op. cit., p. 220.
} 
reglementeze, cu titlu de legislație primară, aspecte privitoare la studenți, examene, diplome, aducând efecte implicit și în aria studiilor de doctorat59.

În materia studiilor doctorale se menține numărul minim de ani de studiu într-o specialitate, și anume minim 5 ani, iar acum accentul cade pe conținutul normativ al art. 66 din L. 1912, acesta reglementând regulile principale în privința studiilor doctorale de drept, litere și științe ${ }^{60}$.

Primul alin., care se referă la doctoratul în drept, reglementează, cu titlu de obligație, ca studentul candidat să aprofundeze o specialitate a dreptului, lucru firesc, urmând ca această specializare să fie întreținută și de urmarea a două cursuri speciale, înafară de cele generale. În orice caz, „facultățile de drept vor propune regulamentarea acestor cursuri generale"61, regulamente care desigur, vor rămâne a fi aprobate de „Ministerul cultelor și instrucțiunii”62. De altfel, odată cu L. 1912, „doctorii în drept vor fi dispensați de stagiul în barou, și de jumătate din stagiul cerut pentru a fi numiți în magistratură”63.

În mod straniu, prin legiferarea în mod exhaustiv a domeniilor în care Facultățile de Litere pot elibera diploma de doctor nu se lasă astfel, în teorie, loc pentru apariția unor noi domenii în care se pot elibera diplome de doctor în Litere, decât printr-o altă lege, iar nu un regulament, în cazul în care s-ar dori adăugarea unui nou domeniu doctoral. Astfel, în 1912, Facultățile de litere puteau elibera diploma de doctor în: „a) filologia clasică, b) filologia modernă, c) studii filozofice și d) studii istorice cu geografia”64.

\footnotetext{
59 Fostul art. 61 din L. 1898, care legifera echivalența diplomelor obținute în străinătate se relochează prin L. 1912 în art. 68.

6o Desigur, şi medicină, dar spuneam că medicina nu interesează studiului nostru.

${ }^{61}$ Art. 66 din L. 1912.

62 Art. 65 din L. 1912.

63 Art. 66 din L. 1912.

64 Art. 66 din L. 1912.
} 
La fel se întâmplă și în cazul Facultăților de Științe, care, în mod exhaustiv, poate elibera diplome de doctor doar în: „a) matematici, b) științele fizice, c) științele chimice, d) științele naturale, e) științele aplicate" 65 . Totuși, în cazul acestor domenii, având în vedere laxitatea lor, nu s-ar putea susține că se restrâng prin lege domeniile doctorale, aşa cum s-ar putea susține că sunt restrânse prin lege domeniile doctorale în Facultățile de Litere.

Având în vedere reglementarea prin lege a domeniilor doctorale în cazul facultăților de științe, în 21 Septembrie/4 Octomvrie 1912 apare în M.of.: 137, Partea Oficială, în baza aprobării „Ministerului Cultelor şi Instrucțiunii”, „Decretul Regal relativ la Regulamentul Facultății de Științe Dela Universitatea din București”. Acest regulament reia ideea intervenției regale în eliberarea diplomelor, statuând în art. 9 că atât diploma de doctor cât și cea de licență „sunt concepute în numele M. S. Regelui și vor purtà semnăturile personale ale ministrului instrucțiunii, rectorului universității şi decanului facultăţii, precum și sigiliile ministerului instrucțiunii și al universității”66.

Ceea ce este cel mai interesant este cum Facultatea a speculat regula regală conform căreia studiile de licență sunt de minim 3 ani și cele de doctorat de minim 5 ani, introducând în anii studiilor de doctorat și pe cei de licență, în cazul în care un posibil candidat dorește să urmeze şi studii de doctorat. Practic, doctoratul se putea finaliza și în 2 ani, întrucât „durata învăţământului pentru gradul de licență este de cel puțin trei ani. Pentru

\footnotetext{
65 Art. 66 din L. 1912.

${ }^{66}$ Art. 9. R. Facultății de Ştiințe Dela Universitatea din București, 1912.
}

\section{6}


doctorat această durată este de cel puțin cinci ani, în care se socotesc și anii ceruți pentru licență" ${ }^{67}$.

În linii mari, examenul public de doctorat urmează aceeaşi tradiție de până acum, aceea de a fi construit din susținerea tezei şi un examen oral, fiind susținut din nou în fața unei comisii formate din 3 profesori specializați în acel domeniu doctoral ${ }^{68}$. Rezultatul acordării titlului de doctor, după susținerea examenului de doctorat, este „proclamat imediat de prezident ${ }^{69}$ în public in prezența tuturor membrilor juriului"7o, însă diploma nu era primită de candidat decât după „intervenția” decanului pe lângă „ministerul instrucțiunii prin rectoratul universității pentru eliberarea diplomei de doctor în științe" ${ }^{71}$. Până atunci, doctorul în Științe primea un certificat provizoriu care să țină locul diplomei ${ }^{72}$. „Regulamentul Facultății de Științe Dela Universitatea din București” ajunge să aibă şi un frate geamăn, cel puțin privind studiile doctorale, evident concretizat în „Regulamentul Facultății de Ştiințe din Iaşi”’3.

Deși ar părea că între 1912 și 1918 nu apare legislație şcolară însemnată74, totuşi, la un an după L. 1912, în M.of.: 160 din 17/30 Octomvrie 1913, Partea Oficială, apar regulamentele Facultăților de Drept din București şi din Iaşi, regulamente care detaliază studiile doctorale. Pentru identitate de rațiune, voi prezenta „Regulamentul Facultății De Drept din București”.

\footnotetext{
${ }^{67}$ Art. 10 din R. Facultăţii de Științe Dela Universitatea din București, 1912.

${ }^{68}$ Art. 30 - 35 din R. Facultății de Științe Dela Universitatea din București, 1912.

${ }^{69}$ Care era cel mai vechi profesor titular din comisia de examinare.

70 Art. 36 din R. Facultăţii de Științe Dela Universitatea din București, 1912.

${ }^{71}$ Art. 37 din R. Facultății de Științe Dela Universitatea din București, 1912.

${ }^{72}$ Art. 38 din R. Facultăţii de Științe Dela Universitatea din București, 1912.

73 Publicat în M.of.: 177 din 7/20 Noemvrie 1912, Partea Oficială.

74 Anghel Manolache, Gheorghe Pârnuță, op. cit., p. 346.
} 
Prin aceste regulamente se enumerară cursurile generale și speciale ce vor fi predate la doctorat 75 , împărțite în mod specific pe anii doctorali de studiu $^{76}$ sau se stabilesc diferite taxe de doctorale ${ }^{77}$, dar atenție specială trebuie oferită desigur doctoratului în sine.

Prin urmare, Facultatea de Drept nu mai speculează L. 1912, incluzând în anii doctorali pe cei de licență, ci specifică direct că „durata studiilor de licență este de 3 ani, iar a cursurilor de doctorat va fi de 2 ani”78, iar doar cei care au devenit licențiați în drept se pot înscrie la cursurile de doctorat79, regulamentul nelăsând astfel absolvenții unei alte facultăți, în afară de cea de Drept, să urmeze cursurile doctorale în domeniul dreptului. Examenul de doctorat în domeniul dreptului prinde amploare, nefiind compus doar din susţinerea unei teze și un examen oral, ci titlul de doctor în Drept, după 1913, se conferea doar ,în urma a trei examene anual (sic!)”8o. Dacă primele două examene constară din subiecte de drept prestabilite precum Dreptul Roman, Comercial, Civil sau Internațional Privat, și altele, „examenul al III-lea consista: a) Din o teză de doctorat asupra unui subiect din materiile predate în facultate; b) Discuțiuni asupra unor chestiuni controversate, alese de candidat, în înţelegere cu profesorii din juriul examinator"81, acest ultim examen putând fi susținut oricând în timpul anului ${ }^{82}$, urmând ca desigur, rezultatul să fie dat de „îndată după terminare” ${ }^{3}$, de către o comisiune „din

\footnotetext{
75 Art. 2 și 9 din R. Facultăţii de Drept din București, 1913.

${ }^{76}$ Art. 9 din R. Facultăţii de Drept din București, 1913.

77 Art. 23, 41, 42 sau 52 din R. Facultății de Drept din București, 1913.

${ }^{78}$ Art. 5 din R. Facultății de Drept din București, 1913.

79 Art. 21 din R. Facultății de Drept din București, 1913.

80 Art. 43 din R. Facultății de Drept din București, 1913.

${ }^{81}$ Art. 43 din R. Facultății de Drept din București, 1913.

${ }^{82}$ Art. 44 din R. Facultății de Drept din București, 1913.

83 Art. 44 din R. Facultății de Drept din București, 1913.
} 
cinci profesori, dintre care președintele și unul din membri, va puteà fi aleși de candidat dintre profesorii titulari sau agregați" 84 .

$\mathrm{Cu}$ privire la teza de doctorat, aceasta era supusă atât aprobării profesorului coordonator, cât și decanului, iar regulamentul merge până acolo încât să reglementeze dimensiunile fizice ale tezei ${ }^{85}$, numărul de exemplare ${ }^{86}$, și chiar și mențiunea din cuprinsul tezei conform căreia ,facultatea consideră opiniunile expuse în această lucrare ca proprï ale autorului și nu are a exprimà nici aprobare nici desaprobare"87.

În M.of.: 219 din 2 Ianuarie $^{88}$ 1921, Partea Oficială apare, după înfăptuirea României Mari și „Regulamentul Facultății de Drept din Cluj”. $\mathrm{Cu}$ privire la studiile doctorale, acest regulament rămâne de principiu fidel regulamentelor dezvoltate la București și Iași.

Chiar și aşa, aduce două elemente de noutate în prezentul studiu. Mai exact, împărțirea specialităților în care pot fi susținute doctorate în drept, în „două specialității: doctoratul în științele juridice, doctoratul în științele politice și economice”89. Chiar mai mult, se prevede că „un student poate obține doctoratul în drept din ambele specialități îndeplinind pentru fiecare din ele dispozițiunile prezentului regulament relativ la doctorat"9o, adică să parcurgă cursurile diferite ale celor două specialități, concomitent cu

\footnotetext{
84 Art. 49 din R. Facultății de Drept din București, 1913.

85 Art. 47 din R. Facultății de Drept din București, 1913.

${ }^{86}$ Art. 48 din R. Facultății de Drept din București, 1913.

${ }^{87}$ Art. 47 din R. Facultăţii de Drept din București, 1913.

88 În 1919 se adoptă în mod unitar în Regatul României calendarul Gregorian, sub conducerea guvernului condus de Ion I. C. Brătianu, prin Decretul relativ nr. 1053, publicat în M.of.: 274 din 6/19 Martie 1919, transformând ziua de 1 Aprilie în ziua de 14 Aprilie, înlocuind astfel calendarul Iulian. Practic, ce interesează studiului nostru, din punct de vedere istoric şi numeric, nu vor mai fi specificate două date ale aceluiași nr. de Monitor Oficial.

${ }^{89}$ Art. 7 din R. Facultăţii de Drept din Cluj, 1921.

${ }^{90}$ Art 47 din R. Facultății de Drept din Cluj, 1921.
} 
examenele diferite ale celor două specialități91, și să susțină două teze de doctorat ${ }^{92}$. Situația din Cluj va fi preluată în mod asemănător și în „Regulamentul Facultății de Drept din Cernăuți”93.

În aceleași linii de examinare, dar doar cu numărul anilor de studiu de licență și doctorat diferind, se publică în M.of. și alte regulamente, cele mai multe fiind publicate în perioada 1921 - 1924, dar au existat regulamente, sau modificări concentrate și între anii 1926 - 1927.

5. În anul 1932 se opresc modificările la L. 1898, partea din lege ce reglementa învăţământul superior împreună cu „regulamentele şi dispozițiunile anterioare legï de față, referitoare la învăţământul universitar și contrarii” 94 se abrogă, iar învățământul universitar primește o nouă configurație prin „Legea pentru organizarea învăţământului universitar”95, sub Președintele Consiliului de Miniștri și totodată Ministrul Instrucțiunii, al Cultelor și Artelor, Nicolae Iorga. Legea este apreciată în literatura de specialitate ca una ce a contribuit la consolidarea învățământului românesc de stat ${ }^{96}$. Reglementările privind studenții şi diplomele se fațetează astfel în Capitolul V al L. 1932, întins pe 12 articole, și art. 68 - 79, dar articolele care interesează în mod special studiul doctoral românesc sunt art. $69-71$.

Astfel, prin L. 1932 se stipulează că, prin reguli noi, modificatoare sau abrogând, că: examenul de doctorat se va putea da în tot cursul anului ${ }^{97}$, deci susținerea lui nu va putea fi restrânsă prin regulamentele facultăților pentru

\footnotetext{
${ }^{91}$ Art. 26 și 27 din R. Facultăţii de Drept din Cluj, 1921.

92 Art. 40 - 43 din R. Facultății de Drept din Cluj, 1921.

93 Publicat în M.of.: 108 din 17 August 1921.

94 Art. 96 din L. 1932.

95 Publicată în M.of.: 96 din 22 Aprilie 1932.

${ }^{96}$ Lilia Parhomenco, op. cit., p. 43.

97 Art. 69 din L. 1932.
} 
a fi ținut doar în anumite luni ale anului; nu se mai specifică expres intervenția regală în diplomele de doctor, întrucât acum diplomele de doctor „se eliberează de rectorii Universităților și poartă semnătura rectorului, decanului și posesorului”, dar se vizează sau contrasemnează de către „Ministrul de Instrucție” 98 ; se lasă la latitudinea facultăţilor, prin regulamentele lor proprii, durata studiilor de doctorat, facultățile urmând să aleagă dacă doctoratul va avea o durată de unul sau doi ani99.

În baza L. 1932 se publică în M.of.: 78 din 2 Aprilie 1936 noul „Regulament al Facultății de Drept din București”, stabilește că după 4 ani de licență, candidatul va urma doar un an de studiu de doctorat ${ }^{100}$. Ce aduce acest regulament ca element nou în București, pentru că în Cluj aveam deja această posibilitate, este şansa unui candidat de a dobândi o dublă specializăre doctorală, prin susținerea examenelor doctorale diferite și susținerea celei de-a doua teze de doctorat în cealaltă specializare ${ }^{101}$. În rest, tradiția doctorală în materia dreptului nu suferă modificări de mare importanță în studiul dreptului la București ${ }^{102}$.

În schimb, prin noul „Regulament al Facultății de Filosofie și Litere a

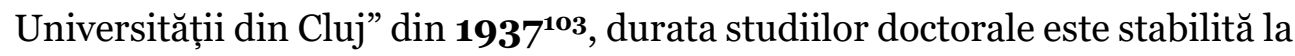
2 ani, consiliul Facultății putând însă „reduce această durata, cu un an, atunci când candidatul dovedește o neîntreruptă activitate științifică în specialitate"104.

\footnotetext{
98 Art. 70 din L. 1932.

99 Art. 71 din L. 1932.

100 Art. 9 din R. Facultății de Drept din București, 1936.

${ }^{101}$ Art. 40 din R. Facultății de Drept din București, 1936.

${ }^{102}$ Art. 41 - 49 din R. Facultății de Drept din București, 1936.

103 Publicat în M.of.: 179 din 6 August 1937.

${ }^{104}$ Art. 9 din R. Facultăţii de Filosofie și Litere a Universităţii din Cluj, 1937.
} 
Ceea ce trebuie notat este că în baza L. 1932, Facultatea de Filosofie şi Litere din Cluj, în 1937 se îndepărteazăă de o tradiție de aproape 40 ani prin care examenul de doctorat până acum consta în atât susținerea tezei de doctorat, cât şi în susţinerea unui examen oral în fața comisiei de examinare ${ }^{106}$, statuând simplu, prin regulamentul său, că: „Examenul de doctorat constă din susținerea orală a tezei”'107. Aceeași examinare doctorală care constă doar în susținerea orală a tezei de doctorat, fără susținerea unui examen oral separat este împărtăşită și de Facultatea de Filosofie și Litere de pe lângă Universitatea din București ${ }^{108}$, prin regulamentul său din $1937^{109}$.

Se revine la intervenția regală, prin aceea că „Diploma de doctor se va elibera de rectorul universității, în numele M. S. Regelui, va purta sigiliul cel mare al universități, va fi semnată de rector, de decanul facultățiii și contrasemnată de ministrul educației naționale"110.

6. În 1942, prin ministrul culturii naționale și al cultelor, filosoful Ioan Petrovici, Mareșalul României și Conducătorul Statului (primulministru) Ion Antonescu decretează „Decretul-lege relativ la organizarea invățământului superior"111, cunoscut sub ca D-L: 386/1942.

În ceea ce privește domeniul doctoral, D-L: 386/1942 nu aduce modificări însemnate, prin art. 122 - 125, cu excepția uneia notabile, evidente având în vedere circumstanțele istorice, prin care intervenția regală din nou este scoasă din discuție: „diplomele se eliberează de Ministerul

\footnotetext{
105 Depărtare nu neapărat împărtășită și de alte facultăți, care mențin examenul oral și susținerea tezei ca două probe distincte ale examenului de doctorat.

${ }^{106}$ Fiind una dintre facultățile care încep astfel o nouă tendință.

107 Art. 37 din R. Facultății de Filosofie și Litere a Universității din Cluj, 1937.

${ }^{108}$ Art. 38 din R. Facultăţii de Filosofie şi Litere de pe lângă Universitatea din București, 1937. 109 Publicat în M.of.: 291 din 16 Decemvrie 1937.

${ }^{110}$ Art. 39 din R. Facultății de Filosofie și Litere de pe lângă Universitatea din București, 1937. ${ }^{111}$ Publicat în M.of.: 118 din 23 Mai 1942.
} 
Culturii Naționale si al Cultelor, prin Rectorat, respectiv directorat, şi poartă semnătura Ministrului, Rectorului respectiv, directorului, decanului și a posesorului. Ele sunt contrasemnate de directorul învățământului superior" ${ }^{112}$.

D-L: 386/1942 ajunge să fie modificată un an mai târziu, prin „Decretul-Lege pentru completarea și precizarea unor dispoziții din legea de organizare a învățământului superior nr. 386 din 1942"113. Tot in 1943, D-L: 386/1942 este republicat în M.of.: 274 din 23 Noemvrie 1943. În ciuda modificărilor și republicării, studiile doctorale nu suferă modificări, iar evoluția și tendințele acumulate până acum cu privire la doctoratul românesc se mențin în aceeași parametri, urmând să sufere majore modificări începând cu anul 1948, și continuând cu anul 1950.

\subsubsection{Concluzii privind perioada $1864-1948$.}

Modelul universitar de inspirație franceză propus prin L. 1864 punea bazele instituționale ale universităților românești, fără a aduce însă și un început pentru studiile doctorale românești, care rămâneau încă un deziderat pentru mai mult de 30 de ani.

Studiile de doctorat pe tărâmul României sunt legiferate odată cu L. 1898, bazată pe modelul german, lege prin care se stabileau condiții comune pentru universități în acordarea titlului de doctor. Numărul minim de 5 ani de studiu într-o specialitate și susţinerea publică a tezei în fața unei comisii de acordare a titlului de doctor devin pași universali de urmat pentru acordarea titlului de doctor, celelalte de îndeplinit pentru acordarea acestui

${ }_{112}$ Art. 124 din D-L: 386/1942.

113 Publicat în M.of.: 244 din 18 Octomvrie 1943.

\section{3}


titlu urmau să se stabilească în comun de către universităţi și minister prin regulamente specifice fiecărei universități.

Anul 1900 aduce legiferarea intervenției regale prin necesitatea emiterii unui decre regal pentru acordarea titlului de doctor. În continuare se mentin specificitățile studiilor doctorale ale fiecărei facultăți, tradusă prin regulamente, și etapa susținerii publice a tezei după minim 5 ani de studiu în specialitate. Tot acum se concretizează la nivelul facultăţilor traditia de a exista un examen oral în paralel cu susţinerea tezei de doctorat.

L. 1912 restrânge competența universităților de a condiționa studiile doctorale prin regulamente, regulamente care acum nu se mai construiau în comun cu ministerul, ci deveneau suspuse aprobării acestuia, și totodată se legifereaza exhaustiv domeniile în care pot fi acordate diplomele de doctor. Cei 5 ani de studiu în specialitate, intervenția regală, susținerea publică și examenul oral sunt elemente ce se păstrează în studiile doctorale.

Anul 1932 aduce cu titlu de lege mențiunea că examenul de doctorat se susține oricând, fără a putea fi restricționat anumite perioade din an prin regulamente. Nu se mai specifică intervenția regală, diplomele fiind eliberate iar doar de universități, celelalte constante râmânând de principiu nealterate.

În 1937 începe tendința prin care se elimină examenul oral de dinainte susţinerii publice a tezei, constatat din 1900, şi se revine la intervenția decretului regal prin lege.

După 5 ani, prin L. 1942 se elimină iar necesitatea decretului regal, dar se mențin aceeaşi parametrii ai studiilor doctorale dezvoltaţi până acum, Anii 1948 - 1950, urma să aducă intervenția masivă a politicului în sfera universitară. $\mathrm{Cu}$ acest prilej perioada incipientă a studiilor doctorale în România care a reprezentat o dezvoltare de la zero a acestor studii, fără a

\section{4}


exista o experiență românească anterioară, urma să fie regândită de la concept, ca şi cum tot ce s-a construit până în 1950 nu ar fi existat.

\subsection{Perioada $1948-1990$.}

2.2.1 Studiile doctorale în regimul comunist.

7. „Decretul nr. 175 pentru reforma învățământului” din 194814, reprezintă legea în baza căreia se vor face marile rupturi față de tradiția doctorală românească pentru următorii 20 ani, cât va sta în vigoare, înainte de abrogarea lui prin L: 11/1968.

Conform unei opinii, prin D: 175/1948, școala românească primește o lovitură, care schimbă cursul firesc al dezvoltării interbelice ${ }^{115}$. Date fiind circumstanțele istorice bine cunoscute, noua conducere politică, instaurându-şi controlul la București la 30 decembrie 1947, sub umbrela Moscovei, a adoptat D: 175/1948 ca una din măsurile de instituire a unui control deplin asupra statului și populației ${ }^{116}$. Astfel, D: 175/1948 nu a fost altceva decât un pas legislativ decisiv spre comunizarea totală a învățământului, un moment de ruptură față de evoluția tradiției universitară dezvoltate până atunci, dar și un moment de îndepărtare de procesele și tendințele din țările occidentale ${ }^{117}$. D: 175/1948 organizase un învăţământ superior constituit din facultăţi, universități, institute de învățământ superior tehnice, agricole, industriale, pedagogice, artistice, teoretic și practic, după modelul sovietic ${ }^{118}$.

\footnotetext{
114 Publicat în M.of.: 177 din 3 August 1948.

115 Lilia Parhomenco, op. cit., p. 43.

116 Dan Constantin Rădulescu, „Invăţământul românesc 1948-1989 - între derivă și recuperare instituțional-funcțională”, Revista Calitatea Vieții, nr. 3-4, 2006, p. 307.

117 Andrei Florin Sora, Evoluția calificărilor din învățământul universitar românesc 19682011, București, 2011, p. 8. Accesibil și pe http://www.invatamant-superior.ro/wpcontent/uploads/2013/08/Raport istoria calificarilor.pdf.

${ }^{118}$ Dan Constantin Rădulescu, op. cit., p. 309.
}

105 
Privitor la studiile doctorale, D: 175/1948 aduce câteva lămuriri. Astfel, se specifică că „numai universităţile și politehnicile pot decerna titlul de doctor”119, deci institutele de învățământ superior, care aveau „menirea să creeze în primul rând cadre superioare de specialiști destinați producției ca: ingineri, agronomi, medici etc., precum şi profesori pentru învăţământul mediu" ${ }^{120}$ nu puteau conferi diploma de doctor.

De altfel, dacă până acum, din principiu, nu existau condiții de examinare pentru a urma studii de doctorat, ci doar condiții legate de identitate domeniului de licență cu cel al studiilor de doctorat (e.g. trebuia ca un candidat să aibă licența în drept pentru a deveni doctorand în Drept), acum, prin D: 175/1948, cu literă de lege primară, se instaurează regula examenului de admitere la doctorat: „poate urma cursurile pentru doctorat orice absolvent al învățământului superior care reușește la examenul de admitere"121.

Ultima lămurire pe care o aduce D: 175/1948 este referitoare la numărul anilor de studiu doctoral, care e „împietrit” la 3 ani ${ }^{122}$. Totuşi, de notat este faptul că dezvoltarea regulamentelor universităților, deci implicit şi a facultăţilor, urma să se facă doar prin aprobarea politicului, întrucât „Universităţile şi politehnicile depind de Ministerul Învăţământului Public”"123. Spre exemplu, chiar și „numărul locurilor pentru doctorat va fi fixat de Consiliul de Miniștri, în legătură cu necesitățile țării” ${ }^{124}$, necesități care, desigur, erau „decise” de politic.

119 Art. XXII din D: 175/1948.

120 Art. XVIII din D: $175 / 1948$.

${ }^{121}$ Art. XXIII din D: $175 / 1948$.

122 Art. XXIII din D: $175 / 1948$.

123 Art. XVII din D: $175 / 1948$.

124 Art. XXIII din D: 175/1948. 
De remarcat este că prin această reformă, din 1948, în România se revenea la sistemul unei legi organice unice, ca în 1864, și că sistemul după model sovietic a fost preluat, chiar dacă D: 175/1948 se abrogase în 1968, prin legile ulterioare ale învățământului din 1968, 1978 și 1995 ${ }^{125}$. Totuși D: 175/1948 avea anumite deficiențe inerente, urmând ca în perioada de până la 1968, printr-o serie de hotărâri ale Consiliului de Miniștri, golurile de la unele capitole ale acestuia să fie completate ${ }^{126}$.

8. 9. 10. 11. În 1950, se publică, în baza D: 175/1948, trei decrete care priveau, în mod special, condițiile de admitere la doctorat cât și studiile doctorale propriu-zise, decrete care urmau a fi ratificare prin „Legea nr. 4 din 30 mai 1950 pentru ratificarea decretelor emise de Prezidiul Marii Adunări Naţionale în perioada dela 23 Decemvrie 1949 până la 27 Mai 1950”127: „Decretul nr. 13 din 14 Ianuarie 1950 pentru înființarea și organizarea aspiranturii” 128 , „Decretul nr. 14 din 14 Ianuarie 1950 pentru reglementarea aspiranturii în condiții speciale”129 și „Decretul nr. 15 din 14 Ianuarie 1950 pentru organizarea doctoratului”"130;

Prin coroborarea celor trei decrete din 1950, se stabilește un nou sistem al studiilor doctorale, în integralitate diferit de modul în careaceste studii erau concepute înainte de perioada de după instalarea regimului comunist. Astfel, pentru a dobândi doctoratul, un licențiat avea de urmat, în principiu, 6 ani de studiu și cercetare, concretizați în studii de „aspirantură” şi doctorat.

\footnotetext{
125 Dan Constantin Rădulescu, op. cit., p. 308.

${ }^{126}$ Lilia Parhomenco, op. cit., p. 43.

127 Publicată în B.of.: 50 din 8 Iunie 1950.

128 Publicat în B.of.: 4 din 17 Ianuarie 1950.

129 Publicat în B.of.: 4 din 17 Ianuarie 1950.

${ }^{130}$ Publicat în B.of.: 4 din 17 Ianuarie 1950.
} 
În primul rând, candidatul trebuia să urmeze studiile de „aspirantură”, un nou grad de învățământ superior, asupra căreia, desigur „conducerea, îndrumarea și controlul aspiranturii cade în sarcina directă a Ministerului Învățământului Public" ${ }^{{ }_{131}}$. Pentru a urma cursurile „aspiranturii”, candidatul trebuia să susțină mai întâi un examen de admitere în „aspirantură” ${ }^{32}$. Înscrierea la concursul de admitere în „aspirantură” era condiționat de vârstă, candidatul neputând avea mai mult de 40 ani şi de asemenea, trebuia ca acesta să posede o diplomă a unei instituții de învățământ superior în aceeași specializare în care dorea să obțină titlul de candidat în științe ${ }^{133}$, continuând a se nega astfel posibilitatea celor care spre exemplu au obținut licența într-un domeniu să poată să se înscrie la „aspirantură” în alt domeniu. Înscrierea la concurs era și a priori atractivă, întrucât admiterea la concurs, urmată de studiile de „aspirantură” erau răsplătite, în toate cazurile, cu bursă din partea statului, pe toată durata „aspiranturii”"134.

Având în vedere regimul comunist şi influența Moscovei asupra României din acea perioadă, „aspirantura” devenea o instituție nouă, nemaiîntâlnită. Originea estică a ,aspiranturii” se reflecta în însuşi concursul de admitere la „aspirantură”. Pe scurt, concursul de admitere în „aspirantură” „consta din următoarele probe: a) Bazele marxism-leninismului; b) Disciplina în specialitate; c) Limba rusă; e) O altă limbă străină (franceză, germană, engleză)" ${ }^{135}$. Se poate observa cum pentru următorii aproape 20 ani, dacă un student dorea să devină doctor, ca mai departe să

\footnotetext{
${ }^{131}$ Art. 1 și 2 din D: 13/1950.

${ }^{132}$ Art. 6 din D: 13/1950.

133 Art. 7 din D: 13/1950.

134 Art. 9 din D: 13/1950.

135 Art. 8 din D: 13/1950.
}

\section{8}


dorească să devină cadru didactic universitar, acesta trebuia să susțină un examen ce consta în cunoștințe de limbă rusă și marxism-leninism.

După 3 ani de „aspirantură”, care în condiții de excepționalitate academică și științifică putea fi redusă cu acordul ministrului la 2 ani, „aspirantul” urmă să își susțină public teza de „aspirantură”, care făcea obiectul anului 3 în mod special: o teză care trebuia să fie o lucrare (doar)

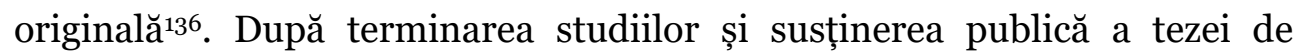
„aspirantură”, în urma promovării acesteia, ,aspirantul” primea din partea „Ministerului Învățământului Public, prin Comisia superioara de diplomă” titlul de „candidat în științe” 137 , titlu care îi era necesar în vederea înscrierii la concursul de admitere la doctorat.

Doctoratul se reorganiza, dar ca „aspirantura”, se afla tot sub conducerea „Ministerului Învățământului” ${ }^{138}$. Pentru a se înscrie la examenul de admitere la doctorat ${ }^{139}$, un candidat trebuia să aibă titlul de „candidat în științe”, pe care îl obținea în urma promovării „aspiranturii”, în acelaşi domeniu în care dorea să urmeze doctoratul ${ }^{140}$. Se observă deci dorința creării unei consecvențe academice fără excepție: licența în drept nu îți permitea, dacă voiai, urmarea „aspiranturii” doar în drept, și apoi studiul doctoral tot doar în drept. Nu se concepea altfel amestecarea academică a treptelor superioare diferite: soarta candidatului era pecetluită odată cu intrarea în studiile de licență.

Foarte asemănător, cu o singură probă diferită față de concursul de admitere în „aspirantură”, ,concursul de admitere pentru doctorat consta în

\footnotetext{
${ }^{136}$ Art. 4 și 5 din D: $13 / 1950$.

137 Art. 5 din D: 13/1950.

${ }^{138}$ Art. 1 şi 2 din D: 15/1950.

139 Art. 5 din D: $15 / 1950$.

${ }^{140}$ Art. 6 din D: 15/1950.
}

\section{9}


următoarele probe: a) Materialismul dialectic și istoric; b) Disciplina în specialitate; c) Limba rusă; d) O limbă străină (franceză, germană, engleză)”. Se observă deci cum limba rusă rămâne pentru următorii aproape 20 ani principala probă de admitere în gradele de învățământ superior. De altfel, marxism-leninismul se transformă ca probă de admitere în „aspirantură”, în materialism dialectic și istoric, ca probă de admitere la doctorat, acesta fiind nici mai mult nici mai puțin decât un concept de filosofie politică marxistă, considerat ca fiind baza gândirii marxiste. Practic, proba filosofiei politice marxiste nu mai apare cu titlul de cunoştințe de bază, ca în cazul „aspiranturii”, ci devine o probă cu caracter de un mai mare grad de dificultate, în vederea admiterii la doctorat. Astfel, candidații în științe trebuiau să se pregătească și să își avanseze cunoașterea în conceptele marxiste dacă doreau să fie admiși la doctorat.

În urma celor 3 ani de stagiu de doctorat ${ }^{141}$, doctorandul trebuia să susţină public o teză care să constea în o lucrare nu doar originală, ca în cazul „aspiranturii”"142, ci trebuia să fie o lucrare „de înaltă calificare științifică”"143. Astfel, singura probă care rămâne între doctorand și titlul de doctor, conferit, la fel ca în cazul „,aspiranturii”, de către „Ministerul Învățământului Public, prin Comisia superioară de diplome”144, este susținerea publică a tezei de doctorat. Se elimină astfel necesitatea susținerii și a unui alt tip de examinare doctorală finală, cum ar fi un examen oral în fața aceleiaşi comisii de examinare a tezei. În acest sesns se legiferează acea tendință de eliminare a

\footnotetext{
${ }^{141}$ Art. 4 din D: 15/1950.

${ }^{142}$ Art. 4 din D: $13 / 1950$.

143 Art. 4 din D: $15 / 1950$.

144 Art. 8 din D: $15 / 1950$.
} 
examenului doctoral final oral constatată și la Facultăţile de Filosofie şi Litere din Cluj și București încă de prin 1937.

Mențiune specială o merită D: 14/1950 („decretul aspiranturii speciale”), care oferă politicului instrumentul prin care profesorii şi conferențiarii nedoriți în sistem puteau fi scoși în baza lipsei titlului lor de candidați în științe. Astfel, deși aceștia erau deja doctori, în baza celor 3 decrete coroborate din 1950, trebuiau să dețină și titlul de candidați în ştiințe, pentru a putea rămâne să activeze în sistemul universitar ${ }^{145}$. Miza acestui decret se materializa într-o anumită recomandare pe care acești profesori trebuiau să o primească pentru a se putea înscrie la concursul de admitere la „aspirantura specială”, recomandare ce era lăsată la latitudinea Consiliilor Instituțiilor de învățământ superior, care urma să fie supusă aprobării de către „Ministerul Învățământului Public” ${ }^{146}$. Fără acea recomandare, „aspiranții speciali” nu se puteau înscrie la concurs, deci nu puteau dobândi titlul de „candidat special în științe”, deci nu puteau rămâne în învățământul superior, care cerea acest titlu, chiar dacă exista deja un titlu de doctor, dobândit anterior anului 1950.

Admiterea la „aspirantura specială” era identică cu cea la doctoratul reorganizat de D: 15/1950 („decretul doctoratului din 1950”)147, iar studiile de „aspirantură specială” erau aproape aceleași cu cele din D: 13/1950 („decretul aspiranturii din 1950”), dar cu specificul dat de faptul că profesorii şi conferențiarii deja aveau un loc de muncă și un doctorat ${ }^{148}$.

\footnotetext{
145 Art. 1 din D: 14/1950.

146 Art. 2 din D: 14/1950.

147 Art. 3 din D: 14/1950.

148 Art. 6 din D: 14/1950.
} 
Timp de 17 ani, învățământul doctoral continuă să funcționeze fără alte intervenţii legislative semnificative. Totuși, în 1967, sub conducerea începută în 1965 de către Nicolae Ceaușescu, studiile doctorale suferă modificări, datorită abrogării tacite/implicite a decretelor din 1950.

12. 13. 14. Prin „Decretul nr. 1058 din 15 Noiembrie 1967 privind titlurile științifice în Republica Socialistă România” 149 și „Hotărârea nr. 2910 din 29 Noiembrie 1967 pentru aplicarea Decretului nr. 1058/1967 privind titlurile științifice în Republica Socialistă România"150, se instaurează un nou, destul de schimbat, sistem de studii doctorale, dar care se racordează la aceleași principii de învățământ superior începute în 1948.

Contextual: „Legea nr. 11 din 13 Mai 1968 privind învățămîntul în Republica Socialistă România” ${ }^{151}$, deși a fost adoptată în anul 1968, urma să devină cadrul legal primar pentru decretul și H: 2910/1967. Prin această lege din 1968 s-au rezolvat probleme privind conținutul inadecvat și contraproductiv ce a fost generat în plan instituțional și organizatoric de D: 175/1948 ${ }^{152}$. Prin aceeași lege, din 1968, se specifică clar că „toate dispozițiile legale contrarii prevederilor din prezenta lege", anume L: 11/1968, se abrogă ${ }^{153}$, însă D: 1058/1967 şi H. 2910/1967 nu conțineau dispoziții contrare cu această lege în ceea ce privește studiile de doctorat. L: 11/1968 nu conținea norme privitoare la studiile doctorale decât în 2 articole, care, în termeni generali, doar expuneau că doctoratul se obține în vederea „obținerii unei înalte calificări științifice de specialitate”154 și că organizarea studiilor

\footnotetext{
149 Publicat în B.of.: 100 din 15 Noiembrie 1967.

150 Publicată în B.of.: 101 din 1 Decembrie 1967.

${ }^{151}$ Publicată în B.of.: 62 din 13 Mai 1968.

${ }^{152}$ Dan Constantin Rădulescu, op. cit., p. 311.

153 Art. 236 din L: 11/1968.

154 Art. 186 din L: 11/1968.
} 
generale „sînt reglementate de lege” 155 , reglementare deja materializată în D: 1058/1967 și H: 2910/1967. Astfel, D: 1058/1967 și H: 2910/1967 ajung să reglementeze studiul doctoral până în 1978, când se emite L: 28/1978.

Revenind la anul 1967, vom încerca să expunem modificările sau noutăţile legislative cele mai importante aduse de D: 1058/1967 și H: 2910/1967. În primul rând, admiterea la doctorat se împarte în două categorii, cea care consta într-un examen de admitere la doctorat, pentru candidațiii ce doreau bursă doctorală, sau colocviu, pentru cei care nu doreau bursă doctorală ${ }^{156}$. Admiterea la doctorat nu mai era condiționată de terminarea „aspiranturii”, care era abrogată, ci doar de terminarea studiilor într-o instituție de învățământ superior ${ }^{157}$. Cel mai important aspect, de noutate, este faptul că, din 1967, nu mai exista o condiționare atât de strictă referitoare la licența candidatului, care trebuia să fie în exact acelaşi domeniu precum studiile sale doctorale. Astfel, începând cu 1967, „la examenul sau la colocviul de admitere se pot prezenta persoanele care au absolvit instituții de învăţămînt [...] în specialitatea la care s-au înscris, sau într-o specialitate înrudita din aceeași ramură de știință”158. Prin urmare, terminarea Facultății de Drept, spre exemplu, îți permitea înscrierea la admiterea într-un doctorat „înrudit” cu științele juridice. Tot cu privire la admiterea la doctorat, în 1967 se introduce noul sistem al pragului notei de admitere: „media minima de admitere este 7 "159.

\footnotetext{
155 Art. 187 din L: 11/1968.

${ }^{156}$ Art. 6 din D: $1058 / 1967$.

${ }_{157}$ Art. 7 din D: 1058/1967.

${ }_{158}$ Art. 3 din H: 2910/1967.

159 Art. 5 din H: 2910/1967.
} 
În al doilea rând, se introduce, prin D: 1058/1967, împărţirea studenților doctoranzi în doctoranzi bursieri și doctoranzi fără bursă ${ }^{160}$. De asemenea, doctoranzii bursieri urmau să facă studii doctorale timp de maxim 3 ani, în timp ce doctoranzii fără bursă urmau studii doctorale de maxim 4 ani161. În timpul doctoratului, doctorandul trebuia să promoveze între 2 şi 4 examene doctorale ${ }^{162}$, la care era necesar să promoveze pentru fiecare examen în parte, cu nota $7^{163}$.

La finalul studiilor doctorale, candidatul trebuia să susțină o teză de doctorat ${ }^{164}$, fără a mai fi nevoie de a susține acel examen oral final de doctorat din vechea perioadă. După susținerea publică a tezei de doctorat, comisia de doctorat hotăra asupra acordării titlului de doctor ${ }^{165}$. Apoi titlul de doctor trebuia să fie confirmat de către Comisia superioară de diplome ${ }^{166}$, din subordinea „Ministerului Învățământului”. După confirmarea de către Comisia superioară de diplome a titlului de doctor acordat de către comisia doctorală, „diploma de doctor se conferă de rectorul instituției de învățămînt superior sau de președintele secției de specialitate a Academiei Republicii Socialiste România”"167.

Mai trebuie menționat că, referitor la cei care obținuseră titlul de candidat în științe, în urma studiilor de „aspirantură”, și titlul de doctor, în baza decretelor din 1950, se instituia un oarecare regim special, prin care titlurile lor evoluau în titluri superioare, întrucât titlul de candidat în ştiințe

\footnotetext{
${ }^{160}$ Art. 5 din D: $1058 / 1967$.

${ }^{161}$ Art. 5 din D: $1058 / 19677$ şi art. 9 din H: 2910/1967.

162 Art. 10 din D: 1058/1967.

163 Art. 14 din H: 2910/1967.

164 Art. 12 din D: 1058/1967.

165 Art. 13 din D: 1058/1967.

${ }^{166}$ Art. 16 din D: 1058/1967.

167 Art. 26 din H: 2910/1967.
} 
se transforma în titlul de doctor, iar titlul de doctor se transforma în titlul de doctor docent (titlu care permitea conducerea de doctorate), în baza D: 1058/1967: „Titlul de candidat în științe confirmat sau recunoscut de Comisia superioară de diplome este echivalat de drept cu titlul de doctor, iar titlul de doctor în științe este echivalat de drept cu titlul de doctor docent în ştiinţe"168.

Acest cuplu, decret-hotărâre, din 1967, urmează să rămână în vigoare până în 1978.

15. „Legea nr. 28 din 21 Decembrie 1978 legea educaţiei și învățămîntului”'169 ajunge să fie ultima lege privind învăţământul care să fie dată până în anul 1995, lege prin care de asemenea se reglementa desigur şi cu privire la studiile doctorale. Această lege, din 1978, avea şi scopul de actualiza învățământul românesc, peticit prin Hotărârile Consiliului de Miniștri sau decretele din perioada 1968 - 1978 170 . Pe de altă parte, s-a apreciat că s-a creat o situație mai dificilă, întrucât deși L: 28/1978 nu se justifica din punct de vedere instituțional, din inițiativa cuplului dictatorial s-a emis, de fapt, o lege prin care se instituia un control riguros al instituțiilor școlare de către autoritățiiti1.

Pentru L: 28/1978, doctoratul devenea, simplu, o altă ,formă de perfecționare a pregătirii personalului muncitor" ${ }^{172}$, iar controlul instituției doctorale românești se reflecta prin controlul politic asupra acestei instituții, control ce era lăsat la latitudinea politicului prin prisma faptului că „modul

\footnotetext{
168 Art. 19 din D: 1058/1967.

169 Publicată în B.of.: 113 din 26 Decembrie 1978.

${ }^{170}$ Adrian Ștefan Chiriac, „Învățământul românesc - de la impas la criză”, Revista de Politica Ştiinței şi Scientometrie - Serie Nouă, vol. 1, nr. 4, 2012, p. 295; Lilia Parhomenco, op. cit., p. 44 .

${ }^{171}$ Dan Constantin Rădulescu, op. cit., p. 313.

${ }^{172}$ Art. 23 lit. h) din L: 28/1978.
} 
de organizare a admiterii la doctorat, a stagiului de pregătire a doctoranzilor și de obținere a titlului științific de doctor se stabilesc prin decret al Consiliului de Stat"173. Practic, se ajunge la situația în care în lege să nu se mai specifice nimic referitor la conținutul studiul doctoral, diferit de cum se întâmpla chiar și în 1968, când totuși existau prevederi legale prin care au fost explicate şi reglementate anumite proceduri și condiții. Acum, totul era lăsat la îndemâna Consiliului de Stat. Deși Consiliul Profesoral al Facultății „acorda titlul științific de doctor” ${ }^{174}$, acesta tot trebuia confirmat de către „Ministerul Educației şi Învățămîntului”, care de altfel „organizează, prin instituțiile de învățămînt superior, învățămîntul postuniversitar și doctoratul" 175 .

Înainte de a încheia, alte mențiuni și specificații, care, după cum spuneam, nu mi-au mai fost accesibile datorită represivității sistemului comunist între 1978 și 1989, trebuie concluzionat totuși că, luată ca un întreg, perioada 1948 - 1989 a reprezentat, pentru învățământul din România, o etapă de acumulări moderne şi progrese notabile, înregistrate mai ales între 1950-1980, în ceea ce privește, promovarea accesului la educație pentru toți cetățenii României ${ }^{176}$, care pe de altă parte, au venit cu la fel de mari nedreptăți bine cunoscute, care urmau a fi soluţionate în primul an postrevoluționar și prin Hotărârea Guvernului nr. $5^{21}$ din 1990177.

\footnotetext{
173 Art. 99 din L: 28/1978.

174 Art. 157 lit. j) din L: 28/1978.

175 Art. 173 lit. j) din L: 28/1978.

${ }^{176}$ Dan Constantin Rădulescu, op. cit., p. 318.

177 Lilia Parhomenco, op. cit., p. 44.
} 
2.2.2 Concluzii privind perioada aniilor 1948-1990.

În 1948 se decretă practic intervenția aproape totală a politicului in sfera academică. În planul studiilor doctorale se legiferează pentru prima dată examenul de admitere la doctorat și anii de studii doctorale se stabilesc la 3 ani. Dup 2 ani, ca si urmare firească a vremurilor, se înființează „aspirantura”, un precursor al studiilor masterale de din zilele noastre, o etapă de studii superioare care se interpunea între licență și doctorat, care presupunea continuarea studiilor în aceeaşi specializare ca licența şi un examen de admitere de o profundă origine estică. După 3 ani de ,aspirantur” şi susţinerea unei teze, candidatul se putea înscrie la doctorat, dar tot în același domeniu de studii. Se menține prin lege examenul de admitere la doctorat, cu o tematică marxist-leninistă avansată. În urma a 3 ani de studii doct orale, candidatul urma doar să își susțină public teza, legiferându-se astfel tendința remarcată de prin anul 1937 de eliminare a examenului oral.

L. 1967 abrogă ,aspirantura” și menționează faptul că un candidat nu mai erai limitat la aceeaşi specialitate, dar trebuia ca studiile doctorale ce dorea să le urmeze să fie cel puțin înrudite cu studiile de licență. Se introduc prin lege examenele doctorale şi conceptul notelor minime de promovare, se menține etapa finală solitară a susținerii tezei, urmând ca ministerul să confirme acordarea titlului de doctor de către universitate.

Deşi prin L. 1978 se elimină radical intervenția universităților în emiterea condițiilor acordării titlului de doctor, care acum urmau să se stabilească strict prin Consiliul de Stat, de principiu se păstrează paşii construiți în 1967.

Perioada comunistă a studiilor doctorale devenea o nouă experiență în studiile doctorale, fără prea mare legătură cu evoluția acestor studii în perioada de dinainte de 1948, perioadă în care s-a regândit apropare integral 
sistemul acordării titlului de doctor, regândire care urma să se propage şi după Revoluția din 1989 și să se păstreze prin multe elemente si după 1990 şi 1996.

\subsection{Anii $1990-1995$.}

2.3.1 Doctoratul care aștepta Legea din 1995 și Hotărârea din 1996.

16. 17. 18. „Hotărârea nr. 521 din 12 Mai 1990 privind organizarea şi funcționarea învățămîntului în România în anul școlar (universitar) 1990/1991”178, „Hotărârea nr. 461 din 30 Iunie 1991 privind organizarea și funcţionarea învățământului în România în anul școlar (universitar) 1991/1992”179 şi „Hotarârea nr. 283 din 21 Iunie 1993 privind unele măsuri referitoare la desfăşurarea învățământului în anul şcolar (universitar) 1993/1994"180 sunt cele 3 acte normative care reprezintă cosmetizarea politică a legislației educaționale post-decembriste. Desigur, având în vedere vidul legislativ în toate domeniile de activitate datorat căderii comunismului, reglementarea studiilor doctorale lăsa de dorit, însă ceea ce se realizase prin aceste hotărâri era o combinație, între L: 28/1978, care nu fusese abrogată până în 1995, și aceste hotărâri de guvern, ce asigura un cadru operațional adecvat situației de tranziție de la începuturile democrației.

Astfel, dacă prin H: 521/1990 doar se amintește că doctoratul este elementul cuprins în sistemul de învăţământ românesc în anul şcolar aferent ${ }^{181}$, prin $H:$ 461/1991 se definește din nou doctoratul, în aceeași parametrii ca în perioada comunistă: „doctoratul constituie forma

\footnotetext{
178 Publicată în M.of.: 71 din 16 Mai 1990.

179 Publicată în M.of.: 157 din 25 Iulie 1991.

180 Publicată în M.of.: 171 din 22 Iulie 1993.

${ }^{181}$ Art. 1 din H: 521/1990.
} 
superioară de perfecționare a pregătirii profesionale a specialiștilor în diferite ramuri ale ștïnței, tehnicii și culturï, prin aprofundarea specializării atestate prin diploma de licență"182. De această dată, în mod necesar, date fiind circumstanțele post-decembriste, doctoratul cade iar la îndemâna politicului (de tranziție înspre democrație însă, de data aceasta), întrucât H: 461/1991 lasă la latitudinea „Ministerului Învăţământului și Științei” „modul de organizare a admiterii la doctorat, desfășurarea activităților în perioada stagiului de pregătire a doctoranzilor și susținerea tezelor în vederea obținerii titlului științific de doctor"183. H: 283/1993 devine o copie fidelă a celei din 1991 în ceea ce privește studiul doctoral.

19. 20. „Legea nr. 84 din 24 Iulie 1995 Legea învățământului”"184 reprezintă pasul istoric educațional de revenire la o educație contextualizată de democrație. Prevederile conținute de diversele hotărâri de guvern din perioada 1990 - 1995 au fost revizuite și completate odată cu aprobarea L: 84/1995, o lege organică care reușește să reglementeze problemele învăţământului de tranziţie.

În baza L: 84/ 1995, se emite „Hotărârea nr. 301 din 30 Aprilie 1996 privind organizarea și desfăşurarea doctoratului” ${ }^{85}$, care deși ajunge să reia tradiții vechi și proceduri din perioada comunistă, ajunge să introducă și elemente nemaiîntâlnite, care merită analizate cu ocazia altui studiu.

2.3.2 Concluzii privind perioada anilor 1990 - 1995.

Datorită circumstanțelor istorice, evoluția legislativă conturată din anul 1967 și condimentată în anul 1978 a studiilor doctorale urma să se

\footnotetext{
182 Art. 39 din H: 461/1991.

183 Art. 40 din H: 461/1991.

184 Publicată în M.of.: 167 din 31 Iulie 1995.

185 Publicată în M.of.: 102 din 20 Mai 1996.
} 
păstreze până în anul 1995 și 1996, urmând să se construiască de această dată studiile doctorale pe fundații puse atât în perioada comunistă, peste care sau pus cărămizi de tranziție înspre studii doctorale într-o țară din nou democratică.

\section{Concluzii finale.}

Conceptul constant nealterat de-a lungul celor aproape 121 de ani ${ }^{186}$ a rămas desigur şi liantul pe care se bazează întreaga experiență doctorală românească: susținerea publică a tezei de doctorat. În jurul acestui concept a susținerii publice am observat cum în funcție de perioada istorică, evoluția legislativă a studiilor doctorale în România a suferit diferite modificări sau nuanțări prin elemente precum: decrete regale, examene orale, examene de admitere, trepte de studii superioare interpuse între licență și studiile de doctorat ș.a., elemente care au fost legiferate, abrogate și reintroduse prin lege în funcție de principiul care stătea în spatele fiecărei legi a învăţământului: gradul de autonomie universitar acordat prin lege în condiționarea acordării titlului de doctor de către universități, grad care diferea și de la un deceniu la altul.

Pe baza a două experiențe diferite, prin H. 1990 - 1993, L: 84/1995 şi H: 301/1996 au fost preluat multe din elementele perioadei incipiente ale studiilor doctorale cât și ale perioadei comuniste, anii 1898 -1989 urmând să aibă reverberații în ceea ce urmau să devină studiile doctorale de între 1990 şi 1996. Chiar şi după 1996, peste aceste fundații am construit ulterior, cu ajutorul unor cărămizi ce aduceau elemente noi, dar și cu cărămizi ce

186 1898-2019. 
presupuneau în mod necesar elemente tranzitive, alte legi ale educaţiei (2011) și hotărâri ce privesc studiile doctorale. 